\title{
Wnt signalinio kelio reikšmè astmos patogenezei
}

Andrius Januškevičius, Kęstutis Malakauskas

LSMU MA Pulmonologijos ir imunologijos klinika

Reikšminiai žodžiai: Wnt, astma, kvėpavimo takai, bronchų lygieji raumenys, $\beta$ kateninas.

Santrauka. Wnt signalinis kelias - tai organizmo išskiriamų glikoproteinų reguliuojamas kelias, galintis veikti genų transkripciją, citoplazmos pakitimus, viduląstelines $\mathrm{Ca}^{+}$jonų saugyklas. Reguliuodamas ląstelinius procesus, nuo embriono vystymosi iki ląstelių apoptozės, Wnt signalinis kelias garantuoja tinkamą organizmo veiklą ląsteliụ lygmeniu. Wnt signalinis kelias yra svarbus normaliam plaučių vystymuisi bei daugelio plaučiu ligu patogenezejje. Sergant astma, nustatoma padidejusi Wnt ligandų bei transformuojančiu augimo faktorių $\beta 1$ raiška, sukelianti kvėpavimo takų remodeliaciją. Šiame straipsnyje apžvelgiama Wnt signalinio kelio įtaka plaučių ligu, ypač astmos, vystymuisi, įrodant Wnt, kaip tyrimo objekto, svarbą.

\section{WNT SAMPRATA}

Wnt (Wingless/integrase-1) - tai signaliniu baltymu šeima, sudaryta iš 19 skirtingų izoformų hidrofobinių glikobaltymù, randamu žmogaus organizme [1]. Wnt gali aktyvinti du signalinius kelius: kanoninį ir nekanoninị. Šie signaliniai keliai reguliuoja įvairius ląstelinius procesus: embriono vystymąsi, ląsteliụ žūtį, proliferaciją, ląstelių migraciją, gali slopinti naviko augimą bei dalyvauti onkogenezejje [2].

Kanoninis - tai standartinis nuo $\beta$ katenino priklausantis kelias, kuriame Wnt signalai sukelia genu transkripciją [1]. $\beta$ kateninas yra transkripcijos koaktyvatorius, kurio kiekị ląsteleje reguliuoja $\beta$ katenino destrukcijos kompleksas. Jeigu Wnt reguliuojami signaliniai keliai yra neaktyvūs, šis kompleksas palaiko mažą $\beta$ katenino kieki, ji fosforilindamas ir taip nukreipdamas proteolizei [3]. Nuo Wnt priklausomo signalinio kelio atveju WNT ligandai prisijungia prie septynių transmembraniniu receptoriu šeimos, vadinamos Frizzled (FZD) receptoriais, ir (ar) prie mažo tankio lipoproteino receptoriaus (LRP), susijusio su baltymais 5 ir 6 [4]. Suaktyvinti receptoriai perduoda signalą $\mathfrak{x}$ ląstelès vidu per DVL baltymus [5]. DVL baltymu aktyvacija kartu su LRP5/6 fosforilinimu sukelia destrukcijos komplekso inaktyvacija arba suirima - taip sudaromos salygos $\beta$ kateninui kauptis citoplazmoje ir patekti i branduoli. Transkripcijos koaktyvatorius $\beta$ kateninas jungiasi su
TCF/LEF transkripcijos faktorių šeima ir taip sužadina genu transkripciją [6]. Standartinio nuo $\beta$ katenino priklausomo signalinio kelio schema pavaizduota 1 paveiksle.

Nekanoninis - tai nestandartinis Wnt signalinis kelias, kai netvarkingi DVL (angl. dishevelled) baltymai gali suaktyvinti atskirus signalinius kelius, nesusijusius su genu transkripcija, o reguliuoja citoplazmos pakitimus apimant aksino citoskeletą ir viduląstelines kalcio saugyklas [7]. Šiems keliams $\beta$ kateninas itakos neturi, tačiau dažnai jie priklausomi nuo c-Jun-N-terminal kinazès (JNK) suaktyvèjimo ir nuo Ca2+ jonų, kurie suaktyvina kalciui jautrius fermentus [8]. Nestandartinio Wnt signalinio veikimo principas pavaizduotas 2 paveiksle.

\section{WNT SIGNALINIS KELIAS IR SENĖJIMAS}

Senstant mažèja bendra audinio masė, kapiliarų skaičius, sunkiau formuojasi naujos alveolès. Dèl šių priežasčių ir bendro raumenu silpnèjimo plaučiu talpa tampa mažesnè net ir sveiku žmoniu $[9,10]$. Senèjimo procesai skatina plaučių audinio fibrozę bei navikų formavimąsi. Vyresnio amžiaus žmonės dažnai serga kvèpavimo takų infekcijomis, o jos palaiko nuolatinį plaučių audinio pažeidimą. Tai lemia ženklius alveoliu epiteliniu ląsteliu struktūros, funkcijos ir genų raiškos pakitimus ir toliau - lètines plaučių ligas [11].

Distalinių plaučių kamieninès ląstelès, II tipo alveolių 


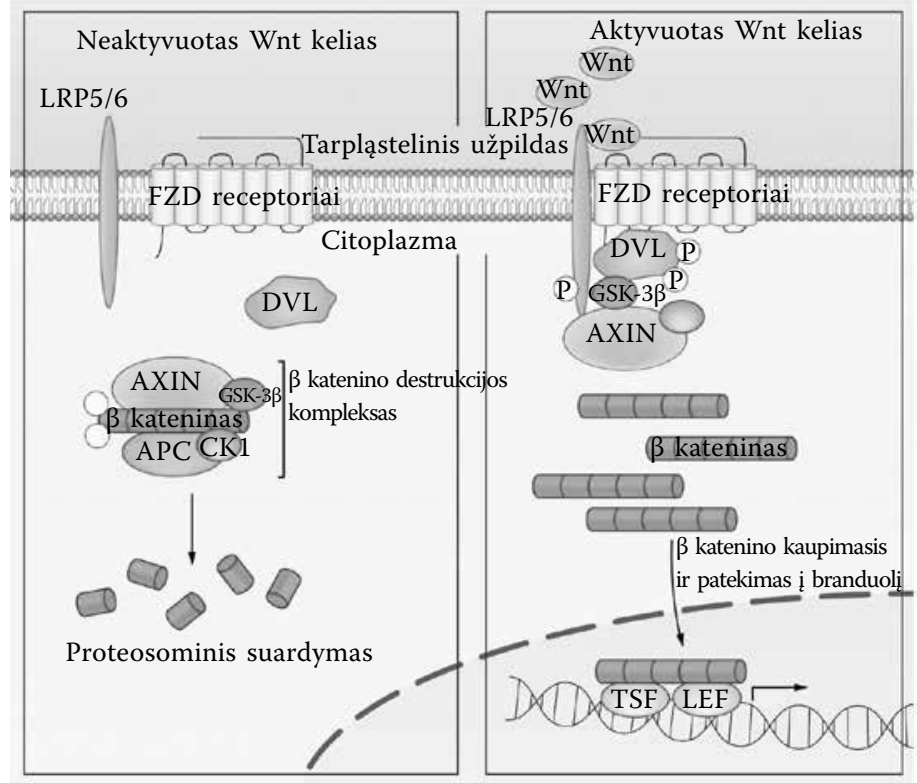

1 pav. Standartinis Wnt signalinis kelias

LRP5/6 - mažo tankio lipoproteino receptorius, susijęs su baltymais 5 ir 6;

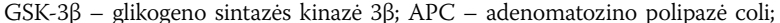

CK1 - kazeino kinazè 1; TCF - T ląsteliu faktorius; LEF - leukemiją skatinantis faktorius.

Kumawat $K$, Koopmans T, Gosens $R ., \beta$-catenin as a regulator and therapeutic target for asthmatic airway remodeling ". Informa healthcare. 2014; Vol. 18, No. 9 , Pages 1023-1034.

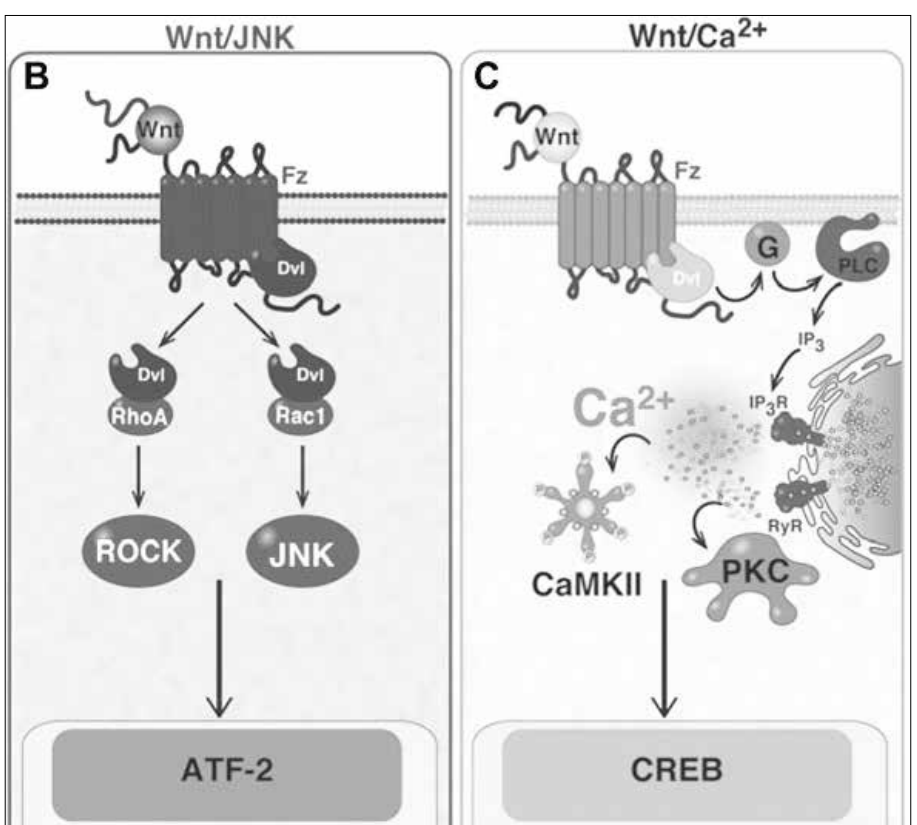

2 pav. Nestandartinis Wnt signalinis kelias

Fz (FZD) - Frizzled receptorių šeima; DVL - netvarkingi (angl. dishevelled) baltymai; G - heterotrimeriniai G baltymai; PLC - fosfolipaze C; IP3 - inozitolio trifosfazè; Rac - Ras šeimos C3 botulino toksino substratas; Rho - GTPazė A; JNK-c-Jun-N-terminal kinazė; ROCK - GTPazės kinazė; PKC - baltymų kinazė C; CaMKII- su kalciu ir kalmodulinu susijusi baltymų kinaze II; CREB - transkripcijos faktorius,

cAMP - elementus jungiantis baltymas; ATF-2 - aktyvuojantis transkripcijos faktorius 2.

http://www.frontiersin.org/files/Articles/57020/fncel-07-00224-HTML/image_m/fncel07-00224-g001.jpg

padidejęs APC geno bei genų, koduojančių Wnt inhibitorius sFRP1, Dkk2 ir WIF-1, hipermetilinimas, kas lemia šių genų nuslopinimą [23]. ląstelès (ATII ląstelès), yra atsakingos už dujų apytakos atkūrimą. Paviršiaus baltymų gamyba ir ATII ląstelių išlikimas priklauso nuo lipofibroblastų - peroksisomų proliferatorių, suaktyvinamų receptoriaus gama (PPAR- $\gamma$ ), priklausančių specifiniam plaučių audinio ląstelių tipui. PPAR $\gamma$ kiekis yra reguliuojamas Wnt molekulių (kanoninio Wnt signalinio kelio), todèl pokyčiai Wnt mikroaplinkoje glaudžiai kontroliuojami - taip išlaikomi distaliniai plaučiai [12]. Išgrynintų epitelinių ir neepitelinių ląstelių realaus laiko PGR analizè atskleidè, kad senstant plaučiuose PPAR- $\gamma$ kiekis sumažèja, o ji reguliuoja Wnt4 ligandas tarpininkaujant $\beta$ kateninui. Senstant plaučiuose padaugeja Wnt4 ir Wnt5a, kurie savo ruožtu didina miofibroblastų tipo diferenciaciją [13].

Žinoma, kad senstant mažeja Klotho ( $\beta$ gliukoronidazès) baltymo kiekis organizme [14]. Klotho - tai Wnt išskiriamas antagonistas, gebantis jungtis su Wnt1, 3, 4 ir 5a. Per daug aktyvus Wnt signalinis kelias, nesant šio inhibitoriaus, lemia audiniui priklausančių kamieninių ląstelių ankstyvos senatvès fenotipo būseną, sąlygojančią silpną regeneraciją ir kamieninių ląstelių išsekimą [15].

Buvo nustatyta, kad evoliuciškai svarbūs ne tik atskiri pagrindiniai ląsteliu signaliniai keliai, bet ir tarpusavyje susijęs jų veikimas ir signalo integracija. Produktyvi sąveika per signalo perdavimo tinklą lemia sẻkmingą embriono organogenezę ir postnatalinio audinio atsistatymą organizmui subrendus. Senatvinè patologija yra susijusi būtent su sutrikusia pagrindinių signalo keliụ - WNT, Notch, TGF- $\beta$, RTK-RAS ir Hh - sąveika [16].

\section{WNT SIGNALINIS KELIAS IR LIGU PATOGENEZE்}

Wnt signalinis kelias yra svarbus daugelio ligu patogenezeje. Vèžio atvejais, ypač jam progresuojant, nustatoma sutrikusi Wnt kelio aktyvacija [1]. Randama $\beta$ katenino mutacijuc, kurios blokuoja GSK3 skatinamą jo fosforilinimą Ser33, Ser37 ir Thr41 pozicijose [17]. Sergant kolorektaline karcinoma, nustatoma nepaveldimu APC (angl. Adenomatous polyposis coli) geno mutacijų, lemiančiu priešlaikinị jo sutrumpèjimą. Šios geno sekos trumpèjimo mutacijos sutrikdo APC jungimąsi prie aksino bei $\beta$ katenino, o to pasekmé - sutrikusi $\beta$ katenino degradacijos komplekso veikla [18]. Nustatyta, kad sergant krūties vẻžiu būna padidèjusi Wnt išskiriamų ligandų raiška (autokrininis signalų perdavimas) arba sumažejjusi tirpių Wnt inhibitorių, kaip antai WIF1 ir sFRP1, raiška [19]. Sergant plaučių vẻžiu, nustatomas sutrikęs Wnt kelio aktyvinimas, kuri gali sąlygoti autokrininis Wnt signalo perdavimas, per didelè teigiamu Wnt tarpininkų ar nuslopinta Wnt antagonistų raiška [20]. Kasos karcinomos atvejais būna padidejęs $\beta$ katenino kiekis (21], taip pat ir HSPG (heparano sulfato proteoglikano, Wnt signalinio kelio reguliatoriaus) raiška [22]. Tuo tarpu sergant inkstų véžiu nustatomas 


\section{WNT REIKŠMĖ FORMUOJANTIS PLAUČIAMS IR SERGANT PLAUČIŲ LIGOMIS}

Wnt signalinis kelias reguliuoja ląstelių diferenciaciją ankstyvosios embriogenezès laikotarpiu vystantis plaučiams [24]. Kiekvienos rūšies ląstelès gali ekspresuoti jai specifiškus Wnt ligandus. Wnt2 randama mezenchimoje, Wnt7b - epiteliniame audinyje, Wnt11 bei Wnt5a - abiejuose audiniuose [25]. Wnt7b yra reguliuojamas skydliaukès transkripcijos faktoriaus-1, kuris yra svarbus alveolių epitelinio audinio diferenciacijai [26]. Sumažèjusi Wnt5a raiška gali sąlygoti padidejusią epitelinių ir mezenchiminių ląsteliụ proliferaciją, padidejjusị distalinị šakojimąsi, sustorèjusị intersticini audinį [27]. Sumažèjus Wnt5a ligando kiekiui, padidejja raiška SHH (angl. Sonic hedgehog), griežtai reguliuojamo baltymo, ịeinančio i̇ plaučių šakojimosi morfogenezę [28]. Dèl ịtakos plaučių audinių morfogenezei Wnt signalinio kelio pokyčiai gali lemti plaučių ligas.

Nustatyta, kad Wnt7b yra svarbus signalo tarpininkas sergant plaučių arterine hipertenzija. Be to, įrodyta, kad transgeniniai Wnt7b sutrikimai, kuriems esant pakinta pirmasis egzonas su LacZ-koduojančiu regionu (WNT7blacZ) sutrikdo mezenchimos audinio bei kraujagysliu augimą ir lemia perinatalinę mirtị dèl kvẻpavimo sutrikimų [29].

Selman su kolegomis nustatè, kad plaučiu fibrozès atveju būna padidejjusi Wnt2, Wnt5a genų, FZD7 ir FZD10 receptorių bei Wnt reguliatorių sFRP1 ir sFRP1 raiška [30]. Sergant plaučiu vėžiu, pokyčiu randama ne pagrindiniuose Wnt signalinio kelio genuose, pvz., APC ar $\beta$ katenino, o Wnt ligandu genuose [31]. Sergant ne smulkiụjų ląsteliu plaučių vèžiu (NSCLC) nustatoma padidejjusi Wnt1 ir Wnt2 raiška, o Wnt7a raiška būna sumažejjusi [32, 33]. Palyginti su adenokarcinoma, esant suragèjusių ląstelių karcinomai, Wnt5a genų raiška būna padidejjusi [34]. Tai rodo, kad Wnt5a raiška yra atsakinga už agresyvias NSCLC formas.

Tyrimai rodo, kad sergant NSCLC Wnt1 ir Wnt2 genu slopinimas lemia véžinių ląstelių opoptozę ir lètesnį naviko augimą [49], o padidejjusi Wnt7a ir FZD9 raiška stabdo ląsteliu transformaciją slopinant ląstelių augimą ir sukeliant epitelinių ląstelių diferenciaciją in vivo ir in vitro [35]. Dar nustatyta, kad aktyvus Wnt signalinis kelias sergant NSCLC yra reguliuojamas per padidejusią tarpląstelinio signalo nešiklio DVL raišką [36].

\section{WNT REIKŠMĖ SERGANT ASTMA}

Astma yra lètinẻ kvėpavimo takų uždegimo liga, kuriai būdingas padidèjęs bronchų reaktyvumas, pasikartojantys sutrikusio bronchų laidumo epizodai, pasireiškiantys veržimu krūtineje, švokštimu, dusuliu ar kosuliu, išnykstantys savaime ar gydant [37].

Astma - tai kompleksinè liga, apimanti tiek genetinius, tiek aplinkos veiksnius. Žmoniu alerginès astmos sukeltos uždegimo reakcijos apima kvẻpavimo takų epi- telinio audinio bei igytos ir iggimtos imuninių sistemų sąveiką, kuri lemia kvépavimo taku struktūros pakitimus [38]. Labiausiai paplitusi yra atopinè astmos forma, kai yra genetinis polinkis ị didesnę specifinių imunoglobulino (Ig) E klasės antikūnų gamybą, kvėpavimo takų reaktyvumą, uždegimo mediatoriu gamybą, pirmo tipo $\mathrm{T}$ limfocitu pagalbininku (Th1) ir Th2 limfocitu imuninio atsako pusiausvyrą [39]. Alergenui patekus i kvejpavimo takus, suaktyveja Th2 limfocitai, skatinamas citokinu išsiskyrimas (IL-4, IL-5, IL-9, IL-13) ir eozinofilinis kvèpavimo takų uždegimas, suaktyvèja B limfocitai, gaminasi IgE klasès antikūnai, kurie, prisijungę prie putliųjų ląstelių, skatina tarpininkų gamybą bei išsiskyrimą ir sukelia nuolatinị kvépavimo takụ uždegimą [41-43].

Lètinèms kvépavimo takų uždegimo ligoms - astmai ir lètinei obstrukcinei plaučiu ligai - būdinga kvèpavimo taku remodeliacija su pakitusia tarpląstelinio užpildo struktūra [48]. Sergant astma, pakitusiuose kvejpavimo takuose vyrauja smarkiai heterogeninè aplinka, kurioje gausu citokinų, augimo faktoriu ir uždegimo tarpininkų, galinčių suaktyvinti nuo $\beta$ katenino priklausomus signalinius kelius [43]. Be to, suaktyvejja transformuojančio augimo faktoriaus- $\beta 1$ (TGF- $\beta 1$ ) raiška, o tai skatina kvèpavimo takų audinių remodeliaciją, sąlygojamą kvèpavimo takų lygiụjų raumenų ląsteliụ tarpląstelinio užpildo gamybos [48]. Kumawat su kolegomis nustatè, kad esant astmai dèl padidejjusio TGF- $\beta 1$ kiekio ženkliai padaugèja ir Wnt5a ligando, o tai gali būti tarpląstelinio užpildo baltymų dereguliacijos priežastis, sukelianti kvejpavimo taku remodeliaciją [50]. Sergant astma, Wnt signalinis kelias aktyvinamas nuolat, dèl to ląsteliu procesai, t. y. proliferacija, išgyvenamumas bei diferenciacija, tampa nekontroliuojami. Wnt signalinis kelias dalyvauja epitelinio audinio ląsteliuc virsme i mezenchimines, sąlygoja stipresni raumeninio audinio susitraukimą, pakitusị bei padidèjusị tarpląstelinio užpildo kaupimąsi, o tai lemia kvèpavimo takų remodeliaciją [43].

Sergant astma, Wnt signalinio kelio sutrikimai yra siejami su kvejpavimo taku pogleivio liauku hipertrofija ir hiperplazija [44], o $\beta$ katenino aktyvumas yra svarbus tinkamam kvejpavimo takų epitelinių ir lygiụjų raumenų ląsteliu vystymuisi ir diferenciacijai, kaip ir plaučiu audinio regeneracijai ir atsikūrimui [45]. Nustatyti ne tik nuo $\beta$ katenino priklausomo signalinio kelio veikimo pakitimai - tirtos ir sąsajos tarp Wnt signalinio kelio genu polimorfizmo (WISP-1 ir Wif-1) ir pablogejusios plaučiu funkcijos [46] bei reikšminga fibroblastų diferenciacijos i miofibroblastus itaka tarpląstelinio užpildo kaupimuisi [47].

Tinkamas Wnt signalinio kelio veikimas svarbus organizmo ląstelinių procesų valdymui. Vis daugejant duomenų apie šio kelio sutrikimų itaką ligų vystymuisi, darosi aktualu ištirti galimas šių sutrikimų priežastis. Padidejjusi Wnt ligandų raiška sergant astma yra svarbus tyrimo objektas tiriant kvèpavimo takų remodeliaciją. 


\section{IMPORTANCE OF WNT SIGNALING PATHWAY IN ASTHMA PATHOGENESIS}

\author{
ANDRIUS JANUŠKEVIČIUS, KĘSTUTIS MALAKAUSKAS \\ DEPARTMENT OF PULMONOLOGY AND IMMUNOLOGY \\ ACADEMY OF MEDICINE LUHS
}

Keywords: Wnt, asthma, airway, bronchial smooth muscle, $\beta$-catenin.

Summary. Wnt signaling pathway - it is secreted glicoproteins regulative pathway, which can act to gene transcription, cytoplacmic changes, intracellular Ca2+ storages. Due to regulation of celullar processes, from embryonic development to apoptosis, Wnt signaling pathway maintain appropriate organism activity at cellular level. Wnt signaling pathway is important to normal lung development and various lung deseases pathogenesis. Asthmatic patients have increased Wnt ligands and transforming growth factors $\beta 1$ expression, which induce airway remodeling. In this review we demonstrate importance of Wnt signaling pathway in lung deseases, especially in asthma pathogenesis.

\section{LITERATŪRA}

1. Saito-Diaz K, Chen TW, Wang X, Thorne CA, Wallace HA, Page-McCaw A, Lee E. The way Wnt works: components and mechanism. Growth Factors. 2013; 31, no. 1:1-31.

2. Chien AJ, Conrad WH, Moon RT. A Wnt survival guide: from flies to human disease." Journal of Investigative Dermatology. 2009; 129, no. 7: 1614-1627.

3. Kimelman, D ir Xu W. Beta-catenin destruction complex: insights and questions from a structural perspective. Oncogene. 2006; 25(57), 7482-7491.

4. Yang-Snyder J, Miller JR, Brown JD, Lai CJ, ir Moon RT. A frizzled homolog functions in a vertebrate Wnt signaling pathway. Curr Biol. 1996; 6(10), 1302-1306.

5. Gao, C., ir Chen, Y. G. (2010). Dishevelled: the hub of Wnt signaling. Cell Signal 22(5), 717-727.

6. Baarsma HA, Königshoff M, Gosens R. The WNT signaling pathway from ligand secretion to gene transcription: molecular mechanisms and pharmacological targets. Pharmacology \& therapeutics. 2013; 138, no. $1: 66-83$.

7. Lai SL, Chien AJ, Moon RT. Wnt/Fz signaling and the cytoskeleton: Potential roles in tumorigenesis. Cell Res. 2009; 19:532-545.

8. Angers $\mathrm{S}$, Moon RT. Proximal events in Wnt signal transduction. Nat Rev Mol Cell Biol. 2009; 10(7), 468-477.

9. Tolep K, Higgins N, Muza S, Criner G, Kelsen SG (1995) Comparison of diaphragm strength between healthy adult elderly and young men. Am. J. Respir. Crit. Care Med. 152, 677-682.

10. Polkey MI, Harris ML, Hughes PD, Hamneg€ard CH, Lyons D, Green M, Moxham J. The contractile properties of the elderly human diaphragm. Am J Respir Crit Care Med. 1997; 155, 1560-1564.

11. Baarsma HA, Spanjer Al, Haitsma G, Engelbertink LH, Meurs H, Jonker MR, Timens W, Postma DS, Kerstjens HA, Gosens R. Activation of WNT/b-catenin signaling in pulmonary fibroblasts by TGF- $b_{1}$ is increased in chronic obstructive pulmonary disease. PLoS ONE 2011; 6 (9), e25450.

12. Talaber G, Kvell K, Varecza Z, Boldizsar F, Parnell SM, Jenkinson EJ, Anderson $\mathrm{G}$, Berki T, Pongracz JE. Wnt-4 protects thymic epithelial cells against dexamethasone-induced senescence. Rejuvenation Res.2011; 14, 241-248.

13. Konigshoff $M$, Eickelberg $O$. WNT signaling in lung disease: a failure or a regeneration signal? Am. J. Respir. Cell Mol. Biol. 2010; 42, 21-31.

14. Arking DE, Krebsova A, Macek M Sr, Macek M Jr, Arking A, Mian IS, Fried L, Hamosh A, Dey S, Mclntosh I, Dietz HC. Association of human aging with a functional variant of klotho". Proc. Natl. Acad. Sci. U.S.A.2002; 99 (2): 856-61.

15. Kuro-o M, Matsumura $Y$, Aizawa $H$, Kawaguchi $H$, Suga T, Utsugi T, Ohyama $\mathrm{Y}$, Kurabayashi M, Kaname T, Kume E. Mutation of the mouse klotho gene leads to a syndrome resembling ageing. Nature. 1997; 390:45-51.

16. Carlson ME, Silva HS, Conboy IM. Aging of signal transduction pathways, and pathology. Experimental cell research, 2008, 314.9: 1951-1961.

17. Laurent-Puig P, Legoix P, Bluteau O, Belghiti J, Franco D, Binot $F$, Monges $G$, Thomas G, Bioulac-Sage P, Zucman-Rossi J. Genetic alterations associated with hepatocellular carcinomas define distinct pathways of hepatocarcinogenesis. Gastroenter-ology. 2001; 120:1763-1773.

18. Segditsas S, Tomlinson I. Colorectal cancer and genetic alterations in the Wnt pathway. Oncogene. 2006; 25:7531-7537.

19. Ugolini F, Charafe-Jauffret E, Bardou VJ, Geneix J, Adelaide J, Labat-Moleur F, Penault-Llorca F, Longy M, Jacquemier J, Birnbaum D, Pebusque MJ. WNT pathway mammary carcinogenesis: Loss of expression of candidate tumor suppressor gene SFRP1 in most invasive carcinomas except of the medullary type. Oncogene. 2001; 20:5810-5817.

20. Akiri G, Cherian MM, Vijayakumar S, Liu G, Bafico A, Aaronson SA. Wnt pathway aberrations including autocrine Wnt activation occur at high frequency in human non-small-cell lung carcinoma. Oncogene. 2009; 28:2163-2172.
21. Zeng G, Germinaro M, Micsenyi A, Monga NK, Bell A, Sood A, Malhotra V, Sood N, Midda V, Monga DK, Kokkinakis DM, Monga SPS. Aberrant Wnt/betacatenin signaling in pancreatic adenocarcinoma. Neoplasia. 2006; 8:279-289.

22. Nawroth R, van Zante A, Cervantes S, McManus M, Hebrok M, Rosen SD. Extracellular sulfatases, elements of the Wnt signaling pathway, positively regulate growth and tumorigenicity of human pancreatic cancer cells. PLoS One. 2007; 2:e392.

23. Awakura $\mathrm{Y}$, Nakamura E, Ito N, Kamoto T, Ogawa O. Methylation-associated silencing of SFRP1 in renal cell carcinoma. Oncol Rep. 2008a; 20:1257-1263.

24. Shannon JM, Hyatt BA. Epithelial-mesenchymal interactions in the developing lung. Annu Rev Physiol 2004;66:625-645.

25. Pongracz JE, Stockley RA. Wht signalling in lung development and diseases. Respir Res 2006;7:15.

26. Minoo P, Hamdan H, Bu D, Warburton D, Stepanik P, deLemos R. TTF-1 regulates lung epithelial morphogenesis. Dev Biol. 1995;172:694-8.

27. Li C, Xiao J, Hormi K, Borok Z, Minoo P. Wnt5a participates in distal lung morphogenesis. Dev Biol 2002;248:68-81.

28. Mucenski ML, Nation JM, Thitoff AR. Beta-catenin regulates differentiation of respiratory epithelial cells in vivo. Am J Physiol Lung Cell Mol Physiol. 2005;289:L971-9.

29. Shu W, Jiang YQ, Lu MM, Morrisey EE. WNT7b regulates mesenchymal proliferation and vascular development in the lung. Development. 2002;129:4831-4842.

30. Selman M, Pardo A, Kaminski N. Idiopathic pulmonary fibrosis: aberrant recapitulation of developmental programs? PLoS Med 2008;5:e62.

31. Ohgaki H, Kros JM, Okamoto Y, Gaspert A, Huang H, Kurrer MO. APC mutations are infrequent but present in human lung cancer. Cancer Lett 2004;207:197-203.

32. He B, You L, Uematsu K, Xu Z, Lee AY, Matsangou M, McCormick F, Jablons DM. A monoclonal antibody against WNT-1 induces apoptosis in human cancer cells. Neoplasia 2004;6:7-14.

33. Yiu L, He B, Xu Z, Uematsu K, Mazieres J, Mikami I, Reguart N, Moody TW, Kitajewski J, McCormick F. Inhibition of WNT-2- mediated signaling induces programmed cell death in non-small-cell lung cancer cells. Oncogene. 2004;23:6170-6174.

34. Huang CL, Liu D, Nakano J, Ishikawa S, Kontani K, Yokomise H, Ueno M. WNT5a expression is associated with the tumor proliferation and the stromal vascular endothelial growth factor: an expression in non-small-cell lung cancer. J Clin Oncol.2005;23:8765-8773.

35. Winn RA, Marek L, Han SY, Rodriguez K, Rodriguez N, Hammond M, Van Scoyk M, Acosta H, Mirus J, Barry N, et al. Restoration of WNT-7a expression reverses non-small cell lung cancer cellular transformation through frizzled-9-mediated growth inhibition and promotion of cell differentiation. J Biol Chem. 2005;280:19625-19634.

36. Uematsu K, He B, You L, Xu Z, McCormick F, Jablons DM. Activation of the WNT pathway in non small cell lung cancer: evidence of Dishevelled overexpression. Oncogene 2003;22:7218-7221.

37. Bateman ED, Hurd SS, Barnes PJ, Bousquet J, Drazen JM, FitzGerald M. Global strategy for asthma management and prevention: GINA executive summary. Eur Respir J 2008:31:143-78.

38. Blume C, Davies DE. In vitro and ex vivo models of human asthma. Eur J Pharm Biopharm Jun 2013;84(2):394-400

39. Ober C, Hoffjan S. Asthma genetics 2006: the long and winding road to gene discovery. Genes Immun. 2006;7:95-100.

40. Amin K, Ludviksdottir D, Janson C, Nettelbladt O, Bjornsson E, Roomans $\mathrm{GM}$. Inflammation and structural changes in the airways of patients with atopic and nonatopic asthma. BHR Group. Am J Respir Crit Care Med. 2000;162:2295-301.

41. Cohn L, Elias JA, Chupp GL. Asthma: mechanisms of disease persistence and progression. Annu Rev Immunol. 2004;22:789-815

42. Kay AB. The role of eosinophils in the pathogenesis of asthma. Trends Mo Med. 2005;11:148-52.

43. Kumawat K, Koopmans T, Gosens R. $\beta$-catenin as a regulator and therapeutic target for asthmatic airway remodeling . Informa healthcare. 2014; Vol. 18, No. 9 , Pages 1023-1034.

44. Driskell RR, Goodheart M, Neff $T$, Liu X, Luo M, Moothart $C$, Sigmund $C D$, Hosokawa R, Chai $Y$, Engelhardt JF. Wnt3a regulates Lef-1 expression during airway submucosal gland morphogenesis. Dev Biol. 2007;305:90-102.

45. Volckaert T, Campbell A, De Langhe S. c-myc regulates proliferation and Fgf10 expression in airway smooth muscle after airway epithelial injury in mouse. PLoS One 2013;8:e71426.

46. Sharma S, Tantisira K, Carey V. A role for WNT-signaling genes in the pathogenesis of impaired lung function in asthma. Am J Respir Crit Care Med. 2010;181:328-36.

47. Dekkers BG, Maarsingh $\mathrm{H}$, Meurs $\mathrm{H}$, Gosens R. Airway structural components drive airway smooth muscle remodeling in asthma. Proc Am Thorac Soc. 2009;6:683-92.

48. Baarsma, HA, Menzen MH, Halayko AJ, Meurs $H$, Kerstjens HA ir Gosen R. $\beta$-Catenin signaling is required for TGF- $\beta 1$-induced extracellular matrix production by airway smooth muscle cells. American Journal of PhysiologyLung Cellular and Molecular Physiology. 2011; 301(6), L956-L965.

49. He B, Jablons DM. WNT signaling in stem cells and lung cancer. Ernst Schering Found Symp Proc. 2006;(5):27-58.

50. Kumawat K, Menzen MH, Bos IST, Baarsma HA, Borger P, Roth M, Tamm $M$. Noncanonical WNT-5A signaling regulates TGF- $\beta$-induced extracellular matrix production by airway smooth muscle cells. The FASEB Journal. 2013; 27, no. 4: 1631-1643. 